\title{
The Journal Of Business Strategies: The First Twenty-Five Years
}

\author{
Sanjay S. Mehta \\ Sam Houston State University • Huntsville, TX \\ Donald Bumpass \\ Sam Houston State University • Huntsville, TX
}

\section{Abstract}

The historical publishing pattern of the Journal of Business Strategies (JBS) is examined. Authors from 171 institutions have written over 262 articles from spring 1984 to fall 2008. Contributions to the journal were studied in terms of numbers of schools represented, number of authors per article, diversity of articles, breakdown of gender of authors, types of citations, and empirical orientation of the articles. Findings indicate that publications in $J B S$ represent a significant scholarly contribution to the field of business strategy. Few differences were detected between $J B S$ and other selected journals. Recommendations to enhance $J B S$ are based on quantitative and qualitative analysis.

\section{Introduction}

The publication of this issue of the Journal of Business Strategies (JBS) marks the end of twenty-five years of publication. With a journal reaching such an important milestone, it is appropriate to look at the journal's history as part of its plans for the future (Malhotra, 1996; Hyman \& Steiner, 1997; Muncy, 1991). Summary articles of single journals have been written for many well-established business journals. For example, The Journal of Advertising (Muncy, 1991), Journal of Accounting Education (Lehman \& Street, 1990), Journal of International Business Studies (Inkpen \& Beamish, 1994; Chandy \& Williams, 1994), Journal of the Academy of Marketing Science (Malhotra, 1996), Journal of Consumer Affairs (Geistfeld \& Key, 1986), Journal of Economic Psychology (Van Raaij, 1986), Journal of Marketing Education (Clark \& Hanna, 1986), Journal of Business Communication (Koch, 1979; Reinsch \& Lewis, 1993), Journal of Marketing (Grether, 1976; Marquardt \& Murdock, 1983), Journal of Finance (Schweser, 1977; Heck, Cooley, \& Hubbard, 1986; Schroeder, Langrehr, \& Floyd, 1995), Journal of Macromarketing (Finn \& McQuitty, 1994), Journal of Applied Business Research (Urbancic, 1994), Journal of Business and Entrepreneurship (Hyman \& Steiner, 1997), Journal of Purchasing and Material Management (Williams \& Oumlil, 1987), Journal of Personal Selling 
and Sales Management (Swan, Powers \& Sobczak, 1991), and Journal of Business Strategies (Mehta, Maniam \& Leipnik, 1999). For the fifteen year anniversary of $J B S$, a retrospective article looked at the first fifteen years of $J B S$. For the twentyfifth anniversary it seems an appropriate time to update that earlier effort.

This paper will once again trace the evolution of $J B S$ from conception to present. More specifically, the article will provide a detailed look at specific aspects of the oldest business strategy journal. A pluralistic research methodology will be utilizing (i.e., both quantitative and qualitative), as it is a more robust than using either one by itself. This article will provide an update to the previous endeavor, which was done a decade ago. Evaluating the current state and statute of $J B S$ is critical in 2008 for two reasons. First, the original editor of JBS, William B. Green, was recently renamed the new editor after twenty-one years. Second, the journal has had a successful twenty-five year history, a silver jubilee of sorts.

\section{History}

$J B S$ was founded in 1982 at the Center for Business and Economic Research, Sam Houston State University (SHSU). Since its inception, $J B S$ has been published semiannually (i.e., spring and fall) by SHSU. The first issue of $J B S$ was published in spring 1984 under the editorship of William B. Green. The first issue mainly contained invited articles from reputable authors to insure that the $J B S$ started off with some quality articles. An important initial objective of $J B S$ was to attract quality articles and to position $J B S$ as a relevant publication appealing to both practitioners and academicians within the business community.

Beginning with the second issue, all articles were double blind reviewed by selected members of the Editorial Board. Editorial Board members are reviewed regularly. Twenty-five years later, the editorial review board includes a diverse group of academic and practitioners from disparate disciplines at reputed institutions. Over the years of its existence, the quality of the Editorial Board has been sustained and continuously improved. During the first fifteen years, the outstanding Editorial Board has elevated $J B S$ 's reputation and established it as a high quality journal with ever improving manuscripts. If there is one criticism that could be alleged, it is the fact that the Editorial Board has lacked adequate international representation.

Susan A. Simmons took over editorial duties in spring 1986 and served through the fall 1986 issue. No significant changes were observed during Simmons' short tenure as the editor of $J B S$. Most of the articles published during both Green's and Simmon's tenure as editor were focused in the area of management strategy. 
In spring 1987, George D. Greenwade became the third editor of $J B S . \mathrm{He}$ immediately instituted three major changes. First, $J B S$ took on a glossy look and changed the binding from saddle-stitch to perfect binding so as it would be more appealing to practitioners. Second, the fall 1987 issue contained a cumulative index of previously published articles. This strategy was important to help increase subscriptions to $J B S$. The practice of indexing previous articles continued for three years. Third, the fall 1988 issue contained the only paid advertisement in JBS's history.

Jo Ann Duffy became the fourth editor of $J B S$ in fall 1990. With one exception, the status quo was maintained during Duffy's tenure as the editor. For the first time, biographical sketches of the authors were published in fall 1991.

In fall 1992, Roger D. Abshire became the fifth editor of JBS. During his brief tenure as editor (i.e., two issues), the Center for Business and Economic Research, where the journal was housed, was renamed the Gibson D. Lewis Center for Business and Economic Development. While this change had a significant impact on the institution, it had no impact on $J B S$ and its editorial staff or board.

Jo Ann Duffy was reappointed the editor in fall 1993 issue and she remained the editor through the fall 2007 issue. During Duffy's second tenure as the editor, she implemented three significant changes. Once again, the cover of the journal received a timely update. Second, a web site (www.shsu.edu/ coba/jbs/board.html) was created for readers and researchers to read articles online and order articles from past issues. Unfortunately, the website is not continuously updated and still lacks the ability to search specific words. Third, current business topics were placed in "special issues" of the journal.

According to Duffy, "Our first two special issues focused on the significant issue of 'Services Marketing' and 'Banking,' where the journal was able to address needs of practitioners." The success and discrimination of the first two special issues was followed by several additional special issues. The next special issue of $J B S$ addressed the timely topic of "Internet Marketing and E-commerce." Due to aggressive marketing of the "Call for papers" by the guest editors, Douglas Kline and Sanjay S. Mehta, the journal received over thirty-five quality submissions. After an extensive review process, it was determined that there were ten articles worthy of publication in the special issue. Due to size and page limitation of $J B S$, two special issues were devoted to the topics of internet marketing and E-commerce (i.e., five articles in each issue) in fall 2001 and spring 2002.

William B. Green was once again appointed the editor of $J B S$ (i.e., prior to the publication of the spring 2007 issue). As JBS prepares for the next decade, Green's 
long-term goals are two-fold. First, to attract articles that are appropriate for business practitioners. Second, identify relevant business topics that justify a "special issue" of $J B S$.

\section{Findings}

\section{Output}

During its first twenty-five years, 262 articles from 573 authors have been published in JBS. As shown in Table 1, the average length of the article was 14.56 pages and the average articles per issue were 5.35. However, over the twenty-five years, there has been a noticeable trend toward longer articles (as measured by number of pages per article). For example, in 1984 the average pages per article were 8.80 and 2007 it was 21.33 pages. This increase in number of pages per article reflects a growing emphasis on the literature review and increased rigor in the methodology section.

The average length of the article is consistent with others journals (14.56 pages for $J B S$ versus 10.5 pages for other journal within business). The mean difference of 4 pages could be attributed to the smaller size ( $9 \times 7$ in) of $J B S$. Next, the average number of articles published per issue is about the same as other journals (Malhotra, 1996; Hyman \& Steiner, 1997). In fact, JBS has attributes similar to other journals, such as number of issues per year and total number of pages per issue.

\section{Authorship}

Many studies use authorship with respect to institutional affiliation or the affiliation tally to gauge the diversity of authors and/or institutions that have published in a particular journal. It is an appropriate measure because institutions of higher education provide various resources and incentives to encourage greater productivity among faculty. Because authorship with respect to institutional affiliation can enhance image and reputation of an institution, many serial retrospectives list the most common institutional affiliations of authors (Hyman \& Steiner, 1997; Carnaghan, Flower-Gyepsi \& Gibbins, 1994; Clark, Hancock \& Kaminski, 1987; Clark \& Hanna, 1986; Fields \& Swayne, 1988; Geistfeld \& Key, 1986; Gentry, Allen \& Vellenga, 1995; Goldsmith, 1983; Hoverstad, Shipp \& Higgins, 1995; Reinsch \& Lewis, 1993; Swan, Powers \& Sobczak, 1991; Wheatley \& Wilson, 1987).

While authors from 138 different institutions have published articles in $J B S$, Table 2 lists the top twenty-seven institutions (i.e., institutions with four or more articles published in the first 49 issues). The table indicates two methods of measur- 
Table 1

JBS Output Per Year from 1984 to 2008

\begin{tabular}{rrrc} 
Year & Number of Articles & Total Number of Pages & \\
\hline 1984 & $5+5=10$ & $41+47=88$ & 8.80 \\
1985 & $5+4=9$ & $47+41=88$ & 9.78 \\
1986 & $5+5=10$ & $51+44=95$ & 9.50 \\
1987 & $5+5=10$ & $47+40=97$ & 9.70 \\
1988 & $6+8=14$ & $52+66=118$ & 8.43 \\
1989 & $8+7=15$ & $77+84=161$ & 10.73 \\
1990 & $7+8=15$ & $65+67=132$ & 8.80 \\
1991 & $6+8=14$ & $76+71=147$ & 10.50 \\
1992 & $9+8=17$ & $85+110=195$ & 11.47 \\
1993 & $6+7=13$ & $78+89=167$ & 12.85 \\
1994 & $6+6=12$ & $82+101=183$ & 15.25 \\
1995 & $6+4=10$ & $98+82=180$ & 18.00 \\
1996 & $5+5=10$ & $106+91=197$ & 19.70 \\
1997 & $5+4=9$ & $82+73=155$ & 17.22 \\
1998 & $4+4=8$ & $72+75=147$ & 18.38 \\
1999 & $5+5=10$ & $105+83=188$ & 18.80 \\
2000 & $5+4=9$ & $86+88=174$ & 19.33 \\
2001 & $5+6=11$ & $99+91=190$ & 17.27 \\
2002 & $5+4=9$ & $93+93=186$ & 20.67 \\
2003 & $5+4=9$ & $72+100=172$ & 19.11 \\
2004 & $4+4=8$ & $94+88=182$ & 22.75 \\
2005 & $4+4=8$ & $73+68=141$ & 17.63 \\
2006 & $5+4=9$ & $91+79=170$ & 18.89 \\
2007 & $5+4=9$ & $104+88=192$ & 21.33 \\
2008 & 4 & 71 & 17.75 \\
Total & $\mathbf{2 6 2}$ & $\mathbf{3 8 1 6}$ & $\mathbf{1 4 . 5 6}$ (mean)
\end{tabular}

* The first number and second number represent the first and second issues respectively.

ing institution affiliations of $J B S$ authors: unweighted and equal weighted authorship. We constructed the unweighted values by assigning weights equal to 1 for first, second, and third authors. The equal weights were constructed by assigning 0.5 and 0.5 for two authors; $0.34,0.33$, and 0.33 for three authors; and $0.25,0.25,0.25$, and 0.25 for four authors. This technique of using unweighted and equal weighted measurement techniques have been previously used (Mehta, Manian \& Leipnik, 1999) and provides a consistent method of measurement to identify trends and promote a better understanding of the journal.

Five universities with the highest authorship in $J B S$ are: Sam Houston State University, Mississippi State University, New Mexico State University, Auburn Uni- 
versity and Louisiana Tech University. Some of these institutions are doctoral granting institutions and all of them are located in the southern half of United States. While this may give the impression that the $J B S$ is only a publication outlet for universities in the South, a look at the entire list, shows that the JBS has published articles from universities located in more than 40 of the 50 states. Sam Houston State University authors have the highest number of publications over the twenty-five year history. While this gives the impression that $J B S$ may be an in-house outlet for Sam Houston faculty, a close examination of articles, shows that 4 of the 10 articles were "introductions to special issues" that were edited by Sam Houston State University faculty members.

Table 2

Institution Affiliation of Authors

Institution

Sam Houston State University

Mississippi State University

New Mexico State University

Auburn University

Louisiana Tech University

University of Texas at San Antonio

Louisiana State University - Baton Rouge

Lamar University

Texas A\&M University - College Station

Southeastern Louisiana University

Kansas State University

University of Texas - Tyler

Eastern Illinois University

lowa State University

Southern Illinois University

Florida Atlantic University

Clemson University

University of North Carolina at Charlotte

Indiana University

University of North Texas

East Carolina University

Middle Tennessee State University

University of Illinois at Chicago

Georgia State University

Texas A\&M International University

University of Arkansas

University of Tennessee at Chattanooga
Unweighted Equal weights

7.84

5.84

7.25

4.84

6.15

4.50

3.00

2.67

2.50

2.40

2.28

4.25

3.17

2.49

2.25

2.10

2.00

2.00

2.00

2.00

2.33

1.97

1.67

1.42

1.34

1.00

1.00 


\section{Diversity}

Given its name and longevity, $J B S$ attracts manuscripts from diverse disciplines. Using Hyman and Steiner (1997) categories of academic areas, Table 3 shows the most published disciplines in $J B S$ are management/organization behavior, finance and marketing. Specifically, $58.4 \%$ of the articles are about management and organizational behavior, $13.0 \%$ are about finance, and $13.0 \%$ are about marketing. Two likely reasons for the high percentage of management and organizational behavior articles in $J B S$ are: (1) its title gives the impression that it is a management strategy journal; (2) the longest serving editor of $J B S$, Duffy, has a Ph.D. in Management and is Professor of Management. It could be argued that she tended to favor and accept greater number of articles within the Management sub-discipline. Contrasting these percentages with those from the fifteen anniversary issue, there continues to be a slight increase of publications in the areas of management and organization behavior. This increase can also be partially attributed the JBS's brief partnership with the Southern Management Association.

Generally, since authors tend to do research in their area of specialization or home disciplines (Geitfeld \& Key, 1986), it is safe to conclude that most authors in $J B S$ are from management, finance, and marketing-related disciplines. Unfortunately, because biographical sketches of the authors were not published prior to 1991, no further conclusion can be drawn regarding the authors primary area of research and teaching.

Table 3

Academic Area of JBS Articles

$\begin{array}{lcr}\text { Academic Area } & \text { Frequency } & \text { Percent } \\ \text { Management/ Organization Behavior } & 15 & 58.40 \\ \text { Marketing } & 34 & 12.98 \\ \text { Accounting } & 13 & 4.96 \\ \text { Finance } & 34 & 12.98 \\ \text { Insurance/ Small Business Entrepreneurship } & 9 & 3.44 \\ \text { Economics } & 7 & 2.67 \\ \text { International Business } & 4 & 1.53 \\ \text { Unknown and Others } & 8 & 3.05 \\ \text { Total } & \mathbf{2 6 2} & \mathbf{1 0 0 . 0 0}\end{array}$




\section{Gender of Authors}

Another criterion used to evaluate journals is the ratio of male to female authors. Similar to other journals, where the ratio of male to female authors is about 4 to 1 (Mehta, Manian \& Leipnik, 1999), the ratio for JBS is roughly the same. Table 4 shows the gender of authors in $J B S$ and indicates that out of 573 authors, 465 $(81.15 \%)$ are male. From the table, it shows the female authors are increasing accordingly because the population growth in female is faster than male. Also, further analysis found that like other comparable journal authors, $J B S$ authors also tend to choose coauthors of the same gender (McDowell \& Smith, 1992).

Table 4

Gender of Authors in JBS

\begin{tabular}{lcc} 
Gender & Frequency & Percent \\
\hline Male & 465 & 81.15 \\
Female & 108 & 18.85
\end{tabular}

\section{Co-authorship}

A growing percentage of articles published in business journals have multiple authors. As noted by Hyman and Steiner (1997), an increasing percent of business and psychology articles published annually are coauthored (Barnett, Ault \& Kaserman, 1988; DuFrene \& Nelson, 1990, McDowell \& Melvin, 1983; Presser, 1980; Schroeder, Langrehr \& Floyd, 1995). This can be attributed to the fact that many recently accredited institutions do not discriminate (i.e., in terms of merit and promotion) between single and multiple author articles.

Urbancic (1992) also concluded that two thirds of accounting articles from 1978 to 1988 that were written by reputable and well-known accounting authors were also coauthored. Similarly, McDowell and Melvin (1983) found that in the area of economics, there is a positive correlation in experience and the probability of co-authorship. In other words, the higher the experience, the higher the probability of coauthoring. We believe that this trend may partly be attributed to the increasing number of schools seeking greater research output from their faculty (i.e., "publish or perish" mentality). Many institutions, especially smaller universities, do not or cannot provide the necessary tools for such productivity (e.g. database, reduced teaching assignment, graduate research assistant). Therefore, co-authors tend to be faculty members from different institutions. 
In $J B S$, only $27 \%$ of the articles (71 out of 262 ) had one author, $37.6 \%$ (99 out of 262) had two authors, $28.5 \%$ (75 out of 262) had three authors, and only $6.8 \%$ ( 18 out of 262) had four or more authors. The percentage of single-authored articles in $J B S$ is significantly lower than in other selected business journals (see Table 5). In fact, the closest journal to JBS is the Journal of Personal Selling and Sales Management (JPSSM) with 49.6\%; all others are above 50\%. On the other hand, the percentage of two author articles in $J B S$ is twice as much as all other journals, except JPSSM (25.2\%). This indicates that authors in $J B S$ contribute fewer single author articles and more two author articles than authors who contribute to other journals. The average number of authors per article for $J B S$ is 2.10 (370/176). The highest average was in 1991, at 2.5, and the lowest average was in 1987, at 1.4.

\section{Table 5}

\section{Single and Multiple Authorship in JBS and Selected Serials}

\begin{tabular}{|c|c|c|c|c|c|c|c|c|c|c|c|c|}
\hline \multirow[t]{2}{*}{ Author } & \multicolumn{2}{|c|}{ JBS } & \multirow{2}{*}{$\begin{array}{l}\text { JBE* } \\
\text { Pct. }\end{array}$} & \multirow{2}{*}{$\begin{array}{l}\text { JM" } \\
\text { Pct. }\end{array}$} & \multicolumn{2}{|c|}{$\mathrm{JM}^{*} \mathrm{JAMS}^{*}$} & \multicolumn{2}{|c|}{$\mathrm{JCR}^{*} \mathrm{JMR}^{*}$} & \multicolumn{4}{|c|}{ MS*JPSSM*JME* Econ ${ }^{*}$} \\
\hline & Freq. & Pct. & & & Pct. & Pct. & Pet. & Pct. & Pct. & Pct. & Pct. & Pct. \\
\hline One & 71 & 27.0 & 77.6 & 77.5 & 77.7 & 76.6 & 67.2 & 70.1 & 64.0 & 49.6 & 90.0 & 57.7 \\
\hline Two & 99 & 37.6 & 15.4 & 14.1 & 14.3 & 15.4 & 18.8 & 15.8 & 19.0 & 25.2 & 9.0 & 16.4 \\
\hline Three & 75 & 27.8 & 3.7 & 5.4 & 5.1 & 4.2 & 6.4 & 7.8 & 9.0 & 11.1 & 1.0 & 7.1 \\
\hline Four & 14 & 4.0 & 1.4 & 1.3 & 1.3 & 1.9 & 3.9 & 2.7 & 4.7 & 7.9 & 0.0 & 4.4 \\
\hline Five or more & 4 & 1.1 & 2.0 & 1.7 & 1.6 & 1.9 & 3.7 & 3.6 & 3.3 & 6.2 & 0.0 & 14.4 \\
\hline $\begin{array}{l}\text { No. of different } \\
\text { authors }\end{array}$ & \multicolumn{2}{|c|}{565} & 299 & 955 & 447 & 520 & 563 & 526 & 300 & 405 & 199 & 13576 \\
\hline $\begin{array}{l}\text { Mean mentions } \\
\text { per author }\end{array}$ & \multicolumn{2}{|c|}{2.15} & 1.4 & 1.4 & 1.4 & 1.4 & 1.6 & 1.6 & 1.7 & 2.0 & 1.1 & 2.0 \\
\hline Years published & \multicolumn{2}{|c|}{$\begin{array}{l}1984- \\
2008\end{array}$} & $\begin{array}{l}1989 \\
1996\end{array}$ & $\begin{array}{l}1960- \\
1981\end{array}$ & $\begin{array}{l}1984 \\
1993\end{array}$ & $\begin{array}{l}1984- \\
1993\end{array}$ & $\begin{array}{l}1984- \\
1993\end{array}$ & $\begin{array}{l}1984- \\
1993\end{array}$ & $\begin{array}{l}1984- \\
1993\end{array}$ & $\begin{array}{l}1980- \\
1993\end{array}$ & $\begin{array}{l}1979- \\
1985\end{array}$ & $\begin{array}{l}1963- \\
1988\end{array}$ \\
\hline
\end{tabular}

Note: JBE is Journal of Business and Entrepreneurship

JM is Journal of Marketing

JAMS is Journal of the Academy of Marketing Science

JCR is Journal of Consumer Marketing

JMR is Journal of Marketing Research

MS is Marketing Science

JPSSM is Journal of Personal Selling and Sales Management

JME is Journal of Marketing Education

Econ is percentages for top 20 Economics journals

*Hyman \& Steiner (1997) 


\section{References}

The impact of other researchers and disciplines on research trends can be analyzed by citation analysis (Hyman \& Steiner, 1997; Chandy \& Williams, 1994; Reinsch \& Lewis, 1993). The average number of references used in an article can reveal how much $J B S$ authors draw from other researchers. The formal definitions of the various citations are given in Table 6 below.

\section{Table 6 \\ Definitions of Citations*}

\begin{tabular}{|c|c|}
\hline Term & Definition \\
\hline Citation & $\begin{array}{l}\text { Publication listed among references at the end of an } \\
\text { article }\end{array}$ \\
\hline Serial & $\begin{array}{l}\text { Periodical published annually or more frequently that } \\
\text { contains articles on various topics }\end{array}$ \\
\hline Book (Scholarly only) & $\begin{array}{l}\text { One-time publication devoted to one topic (including } \\
\text { readings book (essay collection), and handbooks }\end{array}$ \\
\hline $\begin{array}{l}\text { Trade Press/ } \\
\text { Magazines/Newspaper }\end{array}$ & $\begin{array}{l}\text { Newspaper or specialty magazine devoted to narrow } \\
\text { topic (The Wall Street Journal, Financial Times, Forbes, } \\
\text { Business Week) }\end{array}$ \\
\hline $\begin{array}{l}\text { Proceedings/Conference } \\
\text { Presentation }\end{array}$ & $\begin{array}{l}\text { Published conference proceedings or working paper or } \\
\text { presentations from academic conference }\end{array}$ \\
\hline Other & General interest magazine or other source \\
\hline
\end{tabular}

* Hyman \& Steiner (1997)

Table 7 shows that $J B S$ authors referenced an average of 23.85 citations per article. While the mean number of citations for $J B S$ is lower than Journal of International Business Studies (35.8) and Journal of Business Communication (32.3), it is higher than Journal of Business and Entrepreneurship (20.6), Journal of Accounting Education (11.2), and Home Economics Research Journal (16.9) (Hyman \& Steiner, 1997). Upon further examination, it is interesting to note that there is an upward trend in the number of references cited from 1984 to 2008 in JBS. At the very least it does indicate that $J B S$ authors are using a greater number of references to support their studies. 
Table 7

References and Number of Articles in JBS

\begin{tabular}{|c|c|c|c|}
\hline Year & Number of References & Number of Articles & $\begin{array}{r}\text { Average Num } \\
\text { References pe }\end{array}$ \\
\hline 1984 & $33+71=104$ & $5+5=10$ & 10.40 \\
\hline 1985 & $76+48=124$ & $5+4=9$ & 13.78 \\
\hline 1986 & $59+60=119$ & $5+5=10$ & 11.90 \\
\hline 1987 & $90+77=167$ & $5+5=10$ & 16.70 \\
\hline 1988 & $90+110=200$ & $6+8=14$ & 14.29 \\
\hline 1989 & $173+178=351$ & $8+7=15$ & 23.40 \\
\hline 1990 & $134+140=274$ & $7+8=15$ & 18.27 \\
\hline 1991 & $112+103=216$ & $6+8=14$ & 15.43 \\
\hline 1992 & $177+237=414$ & $9+8=17$ & 24.35 \\
\hline 1993 & $122+196=318$ & $6+7=13$ & 24.46 \\
\hline 1994 & $230+192=422$ & $6+6=12$ & 35.17 \\
\hline 1995 & $252+147=399$ & $6+4=10$ & 39.90 \\
\hline 1996 & $215+227=442$ & $5+5=10$ & 44.20 \\
\hline 1997 & $187+132=319$ & $5+4=9$ & 35.44 \\
\hline 1998 & $183+147=330$ & $4+4=8$ & 41.25 \\
\hline 1999 & $312+173=485$ & $5+5=10$ & 48.50 \\
\hline 2000 & $137+220=357$ & $5+4=9$ & 39.67 \\
\hline 2001 & $234+170=404$ & $5+6=11$ & 36.73 \\
\hline 2002 & $172+275=447$ & $5+4=9$ & 49.67 \\
\hline 2003 & $155+202=357$ & $5+4=9$ & 39.67 \\
\hline 2004 & $173+189=362$ & $4+4=8$ & 45.25 \\
\hline 2005 & $271+190=461$ & $4+4=8$ & 57.63 \\
\hline 2006 & $275+137=412$ & $5+4=9$ & 45.78 \\
\hline 2007 & $263+223=486$ & $5+4=9$ & 54.00 \\
\hline 2008 & 164 & 4 & 41.00 \\
\hline Total & 8,133 & 262 & 31.04 \\
\hline
\end{tabular}

Comparing citation by outlet type for $J B S$ and other selected serials, Table 8 shows that $J B S$ authors cite a larger percent of serials. Serial citations in $J B S$ are $71.8 \%$, compared to $48.9 \%$ for Journal of Business and Entrepreneurship, $55.7 \%$ for Journal of International Business Studies, and 55.7\% for Journal of Business Communication. JBS authors cite a far smaller percentage of books/monograph citations. Books/monographs citations in $J B S$ is $6.9 \%$, compared to $22.4 \%$ for Journal of Business and Entrepreneurship, 37.4\% for Journal of International Business Studies, and $36.0 \%$ for Journal of Business Communication. The difference can be attributed to the fact that serial citations may be more valuable to business strategy issues, since scholarly books can become obsolete and outdated rather quickly. 
Table 8

\section{Citations of JBS}

\begin{tabular}{lcccc} 
& \multicolumn{2}{c}{ JBS } & \multicolumn{2}{c}{ JBS } \\
Citations & Frequency & Percent & Frequency & Percent \\
\hline Serials & 2934 & 71.81 & 2705 & 68.90 \\
Books/ Monographs/Trade Press & 281 & 6.88 & 202 & 5.15 \\
Magazines/ Newspaper Proceedings & & & & \\
Conference & 239 & 5.85 & 372 & 9.48 \\
Presentations papers & 536 & 13.12 & 570 & 14.52 \\
Dissertations/ theses & 1 & 0.02 & 1 & 0.03 \\
Other & 95 & 2.33 & 76 & 1.94 \\
Total & 4086 & 100.00 & 3926 & 100.00 \\
Number of Articles & 176 & NA & 86 & NA \\
Year Published & $1984-1998$ & $1999-2008$
\end{tabular}

The only other difference noted (see Table 8) is that $J B S$ articles have a higher percentage (13.1\%) of Proceedings/Conference presentations papers compared to $4.1 \%$ for Journal of Business and Entrepreneurship, 2.0\% for Journal of International Business Studies and almost no such citations for Journal of Business Communication. JBS has a higher percentage of Trade Press/Magazines and Newspapers (5.8\%) compared to Journal of International Business Studies or Journal of Business Communication, which has none. Only Journal of Business and Entrepreneurship has a higher percentage (14.6\%) than $J B S$. This is in part due to the fact that both $J B S$ and Journal of Business and Entrepreneurship are more practitioner-oriented than other journals (e.g., Journal of International Business Studies). Similar to other journals, JBS cites very few dissertations or other publications.

\section{Empirical Articles}

About $48.25 \%$ ( 126 out of 262 ) of the articles in JBS are empirical. While this is an increase from $43.75 \%$ ten years ago, but this percentage is still somewhat lower than the other surveyed journals. For instance, the Journal of Business and Entrepreneurship had about 63.5\% empirical articles (Hyman \& Steiner, 1997), Journal of Accounting Education had 53\% (Lehman \& Street, 1990), and Journal of Economic Psychology had 66\%. Only the Journal of Macromarketing had a somewhat lower percentage (37.5\%) than JBS (Finn \& McQuitty, 1994). While the empirical articles use various methodologies, most of them are relatively easy to comprehend. This is consistent with the scope of $J B S$ which is orientated to both academicians and practitioners. 


\section{Conclusions}

A survey of $J B S$ for a twenty-five year period reveals that many authors are affiliated with regional institutions and that a relatively small number of the authors published more than one article. It also shows that co-authorship is getting increasing common, a trend noticed by others who have written summary articles (Schroeder, Langrehr \& Floyd, 1995). Also, authors are citing an increasing number of references and a larger variety of sources. Also, the number of pages per articles has been constantly increasing. The largest percentage of citations in $J B S$ is serial publications. The diversity of the articles suggests that the articles are mainly about management, marketing and finance. Similar to other academic journals, JBS is dominated by male authors. The mean number of authors in $J B S$ is 2.10 , which is comparable with other journals.

When William B. Green, the first and current editor, was asked about the future of $J B S$, he said "he is confident that the journal will continue to produce quality articles and that it will be successful in the long run." But he also emphasized that $J B S$ must maintain its current focus of both theoretical and practical orientation in order to be of interest to both academicians and practitioners.

\section{Recommendations}

Personal interviews were conducted with a convenient sample of several editorial board members of $J B S$. Their recommendations and views have been aggregated and summarized below. The primary concern expressed consistently by many of the board members was the similarity in the name between $J B S$ and another journal with an analogous name (i.e., Journal of Business Strategy). In our view, either the editorial board must consider a name change or position $J B S$ differently. It is obvious the William B. Green has decided to pursue the latter.

Further, the editorial board members felt that $J B S$ must attempt to increase its circulation among both academics and practitioners. One possible solution to help boost circulation would be to consider publishing more special issues, and/or increase the number of issues per year from two to three or even four. Another recommended approach to increasing the readership and dissemination of knowledge is to persuade additional abstracting service to either index the abstract or the entire journal. This strategy could be augmented with greater emphasis on maintaining an updated website that is searchable and offers articles for free.

Based on personal interviews with selected editorial board members and the analysis of both past issues of the JBS and other comparable journals, here are some 
additional recommendation that warrant consideration. These include but are not limited to: printing the title, author(s), and abstracts of the forthcoming articles in the current issue; printing the call for papers for special issues in the current issue; securing paid advertisement from large publishers or consulting firms in the business strategy area; adding an editorial preface and introduction to each issue. To make $J B S$ appeal to a wider audience, some new sections could be incorporates into the journal, such as book reviews and software reviews.

Considering the high cost of printing and circulating a journal, one possible solution to offset these expenditures, would be to increase the annual subscription fee (it is presently at $\$ 25.00$ ). Similar to many other journals, an alternative could be to offer a three-tier subscription fee (i.e., individuals, institutions and libraries). To generate additional revenues, another option would be to charge a submission fee for the review process and/or publication fee for all accepted articles. Finally, an annual business strategies conference chaired by the editor would significantly help $J B S$ in generating revenues as well as increasing the visibility of the journal.

Some of these recommendations will be easy to implement while others may require some additional resources. For instance, the call for papers for the special issue can either be published in the biannual issues or mailed out to various institutions whereas hosting an annual conference or increasing the number of issues per year may undertake additional resources. To determine the feasibility of implementing some of the above mentioned recommendations, $J B S$ could hold an annual meeting of the editorial board members at one of the conferences which a majority of the board members attend. Finally, to bring about greater notoriety to the journal, Sam Houston State University may want to consider appointing an "external editor" (i.e., someone from another institution) who is well established and known within the field of business strategy.

\section{Limitations and Future Research}

This study has two key limitations. First, because $J B S$ did not publish biographical sketches of the authors prior to 1991, several other summary and comparisons cannot be undertaken. For instance, the rank of the authors who published in $J B S$ cannot be easily determined. Also, the area of specialization of the authors or area of expertise cannot be determined directly. Second, the study did not attempt to assess how well $J B S$ is received by its readers. A formal survey would have provided these insights. 


\section{References}

Barnett, A. H., Ault, R. W., \& Kaserman, D. L. (1988). The rising incidence of coauthorship in economics: Further evidence. Review of Economics and Statistics, 70(August), 539-543.

Carnaghan, C., Flower-Gyepsi, J., \& Gibbins, M. (1994). A profile of contemporary accounting research: Fall 1984-Spring 1994. Contemporary Accounting Research, 1l(Summer), 251-270.

Chandy, P. R., \& Williams, T. G. E. (1994). The impact of journals and authors on international business research: A citational analysis of JIBS articles. Journal of International Business Studies, 24(4), 715-728.

Clark G. L., Hancock, W., \& Kaminski, P. F. (1987). An analysis of leading contributors to the Journal of Marketing Research: 1964-1985. In 1987 AMA Summer Educators' Conference Proceedings (Susan Douglas, et. al., eds.). Chicago: American Marketing Association, 250-253.

Clark, G. L., \& Hanna, N. (1986). An analysis of the sources of articles in the Journal of Marketing Education since its foundation in 1979. Journal of Marketing Education, 8(Summer), 71-74.

DuFrene, D. D., \& Nelson, B. H. (1990). Effective co-authoring for business communication academicians. Bulletin of the Association for Business Communications, 53(June), 68-71.

Fields, D. M., \& Swayne, L. E. (1988). Publication in major marketing journals: 1960-1986. Journal of Marketing Education, 10(Fall), 36-48.

Finn, A., \& McQuitty, S. (1994). Empirical research in macromarketing. Journal of Macromarketing, 14(Fall), 63-68.

Geistfeld, L. V., \& Key, R. (1986). A decade in perspective 1975-84: Focus and trends in the Journal of Consumer Affairs. Journal of Consumer Affairs, 20(Summer), 65-76.

Gentry, J. J., Allen, B. J., \& Vellenga, D. B. (1995). Affiliation of authors in transportation and logistic academic journals-revisited. Transportation Journal, 34(Spring), 54-62.

Goldsmith, E. B. (1983). An empirical analysis of the Home Economics Research Journal. Home Economics Research Journal, 11(March), 207-214.

Grether, E. T. (1976). The first forty years. Journal of Marketing, 40(July), 63-69.

Heck, J. L., Cooley, P., \& Hubbard, C. M. (1986). Contributing authors and institutions to the Journal of Finance: 1946-1985. Journal of Finance, 41(December), 1129-1140. 
Hoverstad, R., Shipp, S. H., \& Higgins, S. (1995). Productivity, collaboration, and diversity in major marketing journals: 1984-1993. Marketing Education Review, 5(Summer), 57-65.

Hyman, M., \& Steiner, S. (1997). The Journal of Business and Entrepreneurship: The first eight years. Journal of Business \& Entrepreneurship, 9(March), 1-31.

Inkpen, A., \& Beamish, P. (1994). An analysis of twenty-five years of research in the Journal of International Business Studies. Journal of International Business Studies, 24(4), 703-714.

Koch, J. E. (1979). A citation analysis for business communication, Journal of Business Communication, 16(Summer), 45-56.

Lehman, M. W., \& Street, D. L. (1990). A taxonomy of content and citations in the Journal of Accounting Education (1983-1989). Journal of Accounting Education, 8(Spring), 63-75.

Malhotra, N. K. (1996). The impact of the Academy of Marketing Science on marketing scholarship: An analysis of the research published in JAMS. Journal of the Academy of_Marketing Science, 24(Fall), 291-298.

Marquardt, R. A., \& Murdock, G. W. (1983). Analysis of authorship in the Journal of Marketing 1960-1981. Journal of Marketing Education, 5(Fall), 53-57.

McDowell, J. M., \& Smith, J. K. (1992). The effect of gender-sorting on propensity to coauthor: Implication for academic promotion. Economic Inquiry, 30(January), 68-62.

McDowell, J. M., \& Melvin, M. (1983). The determinants of coauthorship: An analysis of the economic literature. Review of Economics and Statistics, 65(February), 155-160.

Mehta, S. S., Manian, B., \& Leipnik, M. R. (1999). The Journal of Businesses Strategies: The first fifteen years. Journal of Business Strategies, 16(Spring), 89-105.

Muncy, J. A. (1991). The Journal of Advertising: A twenty year appraisal. Journal of Advertising, 20(December), 1-11.

Presser, S. (1980). Collaboration and the quality of research. Social Studies of Science, 10, 95-101.

Reinsch, Jr., N. L., \& Lewis, P. V. (1993). Author and citation patterns for the Journal of Business Communication: 1978-1992. Journal of Business Communication, 30(October), 435-462.

Schroeder, D. M., Langrehr, F. W., \& Floyd, S. W. (1995). Marketing journal coauthorship: Is it a hit or a miss with coauthors? Journal of Marketing Education, 17(Summer), 45-58.

Schweser, C. (1977). The doctoral origins of contributors to the Journal of Finance from 1964 through 1975. Journal of Finance, 32(June), 908-910. 
Swan, J. E., Powers, T. L., \& Sobczak, P. M. (1991). Utilization of sales management knowledge and identification of contributors: An analysis of JPSSM 19801990. Journal of Personal Selling \& Sales Management, 11(Winter), 5-16.

Urbancic, F. R. (1994/1995). An analysis of the institutional and individual authorship sources of articles in the Journal of Applied Business Research: 1985-1993. Journal of Applied Business Research, Il(Winter), 108-116.

Van Raaij, W. F. (1986). The first five years of the Journal of Economic Psychology. Journal of Economic Psychology, 7(March), 1-15.

Wheatley, J. J., \& Wilson, L. C. (1987). The origins of published marketing research in the 1980's. In 1987 AMA Summer Educators' Conference Proceedings (Susan Douglas, et. al. eds.). Chicago: American Marketing Association, 260-265.

Williams, A. J., \& Oumlil, B. (1987). A classification and analysis of JPMM articles, Journal of Purchasing and Material Management, 23(Fall), 24-28.

\section{Acknowledgement}

We are grateful to Ms. Mary Yiu, graduate student in the Gibson D. Lewis Center for Business and Economic Development, for her assistance in updating the last ten years of articles published in the Journal of Business Strategies. Her assistance and suggestions improved the quality of our paper.

\section{Biographical Sketches of Authors}

Sanjay S. Mehta (M.S., Ph.D., University of North Texas) is currently Professor of Marketing at Sam Houston State University and winner of the "2005 Excellence in Research" award. He has presented over 125 papers at regional, national, and international conferences and served as track chair, session chair, discussant, and reviewer at many of these conferences. He has published over 75 articles in various proceedings/journals including: Journal of Asian Business, The Cornell H.R.A. Quarterly, Journal of Professional Services Marketing, Health Marketing Quarterly, Journal of Customers Services in Marketing and Management, Southwest Decision Science Institute Proceedings, Southwestern Marketing Association Proceedings, Academy of International Business Proceedings, Academy of Marketing Science Proceedings, American Marketing Association Proceedings, Society of Franchising Proceedings, Atlantic Marketing Association Proceedings, and others. He holds a B.S. in Mathematics and an MBA in Management from Angelo State University.

Donald L. Bumpass (BA, MS, $\mathrm{PhD}$, Oklahoma State University) is currently Professor of Economics at Sam Houston State University. Dr. Bumpass has published over 30 articles in numerous journals including Atlantic Economic Journal, 
Review of Industrial Organization, American Economist, Antitrust Law \& Economics Review, Journal of Economic Education, and Journal of Economics. His research interests include regional economic development and energy. 